\title{
Serological Typing of Strains of Streptococcus faecium and Unclassified Group D Streptococci Isolated from Canned Hams and Pig Intestines
}

\author{
By M. ELISABETH SHARPE AND B. GILLIAN FEWINS \\ National Institute for Research in Dairying, University of Reading, \\ Shinfield, Reading
}

(Received 11 July 1960)

\section{SUMMARY}

A collection of 85 strains of Streptococcus faecium and unclassified group D streptococci isolated from canned hams and pig intestines was typed serologically. Seventy-seven of the isolates, which included two motile strains, were distributed amongst 15 types and 4 subtypes. The distribution of types was widespread, the same type being isolated from several different countries.

\section{INTRODUCTION}

Ingram \& Hobbs (1954) and Ingram \& Barnes (1955) showed that group D streptococci may cause serious spoilage in pasteurized canned hams, particularly as they are able to grow in hams stored at low temperatures. These organisms also occur sometimes in normal hams where their presence may indicate faecal pollution and a potential danger of food poisoning. Elimination of these occasionally surviving organisms by more extensive heat treatment of cans is not always practicable and must be done by determining and eradicating their source. This may be a direct infection from the animal gut or contamination during factory processing. Barnes \& Ingram (1955) identified by physiological tests the faecal streptococci from canned hams as Streptococcus faecium and those predominating from pig intestines as $S$. faecium and unclassified group D strains, no true $S$. faecalis being found; whereas in bacon factories $S$. faecalis predominated (Barnes, Ingram \& Ingram, 1956). Although this suggested that streptococci from canned hams might originate from guts of pigs, a more precise identification than that indicated by physiological characteristics was necessary; we have serologically typed some of the organisms from these sources. As spoilage in canned hams cannot be predicted it was not possible to compare the canned-ham isolates with those from the relevant pigs. The present work was intended to establish the serological types of strains from these sources, rather than to draw conclusions about their epidemiology. Such evidence will be reported later.

Skadhauge (1950) typed group D streptococci from human sources and demonstrated by agglutination tests the presence of heat stable $(O)$ antigens and heat labile $(\mathrm{K})$ antigens. He distinguished 16 different $\mathrm{O}$ antigens among the strains of Streptococcus faecium and 5 among the unclassified and $S$. durans strains. Sharpe \& Shattock (1952) differentiated by agglutination, and confirmed by precipitin tests, 
24 serological types among group $D$ streptococci isolated from faeces of human infants. These included 4 types of $S$. faecium (types 14, 16, 18 and 24), 2 types of $S$. durans, and 7 unclassified types. A further type of $S$. faecium was described by Sharpe (1952), and another was isolated from the gut of the pig by Fewins, Newland \& Briggs (1957).

\section{METHODS}

Eighty-five strains of group D streptococci previously isolated from canned hams and pig guts (Barnes \& Ingram, 1955) and consisting of 56 Streptococcus faecium isolates and 29 'unclassified type $I$ ' isolates, were received from $\mathrm{Dr}$ E. M. Barnes (Low Temperature Research Station, Cambridge). Of these 71 had previously been characterized biochemically by Barnes \& Ingram (1955) and the other 14 by Dr C. F. Niven (personal communication) and Lake, Deibel \& Niven (1957). One isolate was from bacon, 28 were from 20 canned hams, and 56 were from 14 pigs (Table 1). The 'unclassified type I' strains (Barnes et al. 1956) resembled $S$. faecium except that they did not ferment mannitol or arabinose. The types described in the present work were at first defined by agglutination and precipitin typing; the $5 S$. faecium types of Sharpe \& Shattock (1952) and Sharpe (1952) were included for comparison.

Preparation of type sera. (a) Formol treated vaccines. Organisms grown for $18 \mathrm{hr}$. at $37^{\circ}$ in $40 \mathrm{ml} .1 .0 \%(\mathrm{w} / \mathrm{v})$ glucose Lemco broth (GLB) were washed twice in $0.85 \%(w / v)$ saline and suspended in $10 \mathrm{ml} .0 \cdot 25 \%$ formalin $(0.1 \%$ formaldehyde) saline, and stored at $4^{\circ}$. Formalin-treated vaccines were used for preparing all sera unless specified otherwise. (b) Disrupted organisms. Saline suspensions of washed organisms grown in $10 \mathrm{ml}$. GLB medium for $18 \mathrm{hr}$. at room temperature were shaken on the Mickle tissue disintegrator (Mickle, 1948) for $1.5 \mathrm{hr}$. with carborundum powder (Shattock, 1949). A fresh preparation was made for each rabbit inoculation.

With formol-treated and disrupted organisms, rabbits were given a course of five intravenous inoculations of $1.0 \mathrm{ml}$. suspension at 3 to 4 -day intervals. This usually resulted in a potent type serum. When it did not a further course of inoculations was given. Type sera were stored with thiomersalate $(0.01 \%, \mathrm{w} / \mathrm{v})$ as a preservative. Small samples of sera for current use were stored at $4^{\circ}$; the main bulks of sera were kept in $2 \mathrm{ml}$. quantities at $-20^{\circ}$.

Agglutination tests. Bacterial suspensions for agglutination were prepared from 4 to $6 \mathrm{hr}$. cultures incubated at $37^{\circ}$ in GLB medium, the organisms washed and resuspended in the same volume of formol saline and stored at $4^{\circ}$. Such washed suspensions were more stable than formol-killed broth suspensions. Dreyer's agglutination technique was used, and results read after overnight incubation at $\mathbf{5 0}^{\circ}$.

For agglutinin absorption the method described by Sharpe \& Shattock (1952) was followed.

Precipitin tests. $\mathrm{HCl}$ extracts (Lancefield, 1933) were prepared as described by Sharpe \& Shattock (1952). In the earlier part of the work cultures were incubated at $37^{\circ}$, but later incubation at room temperature was used (Elliott \& Barnes, 1959) since in a few cases this resulted in extracts which reacted more strongly with the homologous type sera. Organisms from $10 \mathrm{ml}$. of GLB medium were enough to obtain a potent type extract. Tryptic digest extracts were prepared by Elliott \& Barnes's (1959) method except that strains were grown in GLB medium instead of Todd-Hewitt broth. 
Precipitin ring tests were used for typing, the tubes being read at intervals up to $10 \mathrm{~min}$. A heavy precipitin ring was usually obtained in $3 \mathrm{~min}$. or less with the homologous serum and extract.

Gel diffusion tests were made by Mansi's (1957) modification of Ouchterlony's technique.

For the absorption of precipitins four volumes of sera were absorbed with 1 vol. of packed streptococci previously washed and killed with formalin. Absorption was carried out at $37^{\circ}$ for $2 \mathrm{hr}$., followed by overnight refrigeration.

Physiological tests. Recognized methods for the identification of group D streptococci were used. These included: ability to grow at $10^{\circ}$ and $45^{\circ}$; carbohydrate

Table 1. Serological types and subtypes of strains of Streptococcus faecium and unclassified group $D$ streptococci isolated from porcine sources

\begin{tabular}{|c|c|c|c|c|c|}
\hline \multirow{2}{*}{$\begin{array}{l}\text { Serological } \\
\text { type }\end{array}$} & \multirow{2}{*}{$\begin{array}{l}\text { Type } \\
\text { strain }\end{array}$} & \multirow{2}{*}{$\begin{array}{l}\text { No. of } \\
\text { strains in } \\
\text { type }\end{array}$} & \multirow{2}{*}{$\begin{array}{l}\text { Species of } \\
\text { group D }\end{array}$} & \multicolumn{2}{|c|}{ Source of strains } \\
\hline & & & & Country of origin & Isolated from \\
\hline 16 & $\mathbf{N} / \mathbf{H} 53$ & 3 & faecium & $\begin{array}{l}\text { Holland, U.S.A., } \\
\text { Canada }\end{array}$ & $\begin{array}{l}2 \text { canned hams } \\
1 \text { bacon }\end{array}$ \\
\hline 26 & CH1 & 6 & faecium & Belgium & 1 canned ham \\
\hline & $\mathbf{P 1 2 / 6}$ & 11 & Unclassified & G.B. & 5 pigs \\
\hline $26 \mathrm{~A}$ & CH3 & 4 & faecium & Belgium & 1 canned ham \\
\hline $26 B$ & P15/6 & 3 & Unclassified & G.B. & 3 pigs \\
\hline $26 \mathrm{C}$ & P 15/9 & 3 & Unclassified & G.B. & 2 pigs \\
\hline 27 & CH12 & 1 & Unclassified & S. Africa & Canned ham \\
\hline 28 & HGH511 & 8 & faecium & $\begin{array}{l}\text { Europe, U.S.A., Germany } \\
\text { G.B. }\end{array}$ & $\begin{array}{l}6 \text { canned hams } \\
2 \text { pigs }\end{array}$ \\
\hline 29 & P 14/6 & 2 & faecium & G.B. & 2 pigs \\
\hline 30 & N/GE 4.B & 4 & faecium & Holland, U.S.A., Poland & 4 canned hams \\
\hline 31 & $\mathbf{N} / \mathbf{H}_{2}$ & $\mathbf{1}$ & faecium & Holland & Canned ham \\
\hline 32 & $\mathbf{N} / \mathbf{H} 4$ & 3 & faecium & U.S.A., Holland, Denmark & 3 canned hams \\
\hline $\mathbf{3 3}$ & P3 & 1 & faecium & G.B. & Pig \\
\hline 34 & Pr & 1 & faecium & G.B. & Pig \\
\hline 35 & $\mathbf{N} / \mathbf{R 6 4}$ & 1 & faecium & G.B. & Pig \\
\hline 36 & P1/12 & 2 & faecium & G.B., U.S.A. & 2 pigs \\
\hline 37 & P6/4 & $\overline{5}$ & faecium & G.B. & 3 pigs \\
\hline $37 \mathrm{~A}$ & P4/16 & 13 & faecium & G.B. & 7 pigs \\
\hline 38 & P20/5 & 2 & Unclassified & G.B. & 2 pigs \\
\hline 39 & P16/5 & 3 & Unclassified & G.B. & 2 pigs \\
\hline Not typed & & 1 & faecium & Holland & Canned ham \\
\hline & & $\mathbf{1}$ & faecium & G.B. & Pig \\
\hline & & 6 & Unclassified & G.B. & 5 pigs \\
\hline otal & & 85 & & & \\
\hline
\end{tabular}

fermentations; reaction in litmus milk; production of $\mathrm{NH}_{3}$ from arginine; ability to split aesculin; growth on potassium tellurite agar; type of haemolysis (Shattock, 1949 ; Barnes, 1956; Barnes et al. 1956; Fewins et al. 1957). For detection of motility, $6 \mathrm{hr}$. cultures in GLB medium incubated at room temperature, after several transfers incubated at the same temperature, were examined by hanging drop.

\section{RESULTS}

Of the 85 strains of group D streptococci investigated, 77 were distributed amongst 15 types and 4 subtypes (Table 1 ). The types were numbered to extend the 24 types of Shattock \& Sharpe (1952). Sharpe's (1952) serological type of Streptococcus 
faecium was numbered 25 , and the 14 new types described here comprised types 26-39.

Agglutination typing. For the preliminary work agglutination tests were used. Thirteen types were designated, the results being confirmed by agglutinationabsorption tests and by reciprocal absorption tests when necessary. Heterologous cross-reactions occurred but they were eliminated by absorption with appropriate absorbing suspensions. Sometimes sera had to be absorbed with several different strains to obtain complete specificity, which occasionally decreased the titres of the sera. The titres of unabsorbed sera were usually between 640 and 5120, although in a few instances higher or lower titres were obtained. With some of the types $(16,26$, 28, 30, 32 and $37 \mathrm{~A}$ ) antisera were prepared against several different strains within the type, to confirm that they were homologous. Suspensions of previously designated types of Streptococcus faecium (types 14, 16, 18, 24, and 25) were tested against

Table 2. Relationships between serological types and subtypes as shown by precipitin reactions, using absorbed and unabsorbed sera

Type 26 and subtypes $26 \mathrm{~A}, 26 \mathrm{~B}$ and $26 \mathrm{C}$

Reciprocal absorption tests

Absorbed sera

\begin{tabular}{|c|c|c|c|c|c|c|c|}
\hline \multirow[b]{2}{*}{ HCl extract } & \multicolumn{2}{|c|}{ Unabsorbed sera } & \multirow{2}{*}{$\begin{array}{r}\text { T26 abs. T26A } \\
\text { or } \\
\text { T26B } \\
\text { or }\end{array}$} & \multirow{2}{*}{$\begin{array}{r}\text { T26A abs } \\
\text { or } \\
\text { or }\end{array}$} & \multirow{2}{*}{$\begin{array}{l}\text { T26 } \\
\text { T26B } \\
\text { T26C }\end{array}$} & \multirow{2}{*}{$\begin{array}{c}\text { T26 B abs. } \\
\text { or } \\
\text { or }\end{array}$} & \multirow{2}{*}{$\begin{array}{l}\text { T26 } \\
\text { T26A } \\
\text { T26C }\end{array}$} \\
\hline & T26 & T26A T26B & & & & & \\
\hline Type 26 & + & + & - & - & & - & \\
\hline Type 26 A & + & + & - & + & & - & \\
\hline Type 26B & + & + & - & - & & + & \\
\hline Type 26C & + & + & - & - & & - & \\
\hline
\end{tabular}

Type 26C gave similar reactions

Types 37 and $\mathbf{3 7} \mathbf{A}$

$\begin{array}{lcccc}\text { HCl extract } & \overbrace{\text { T37 }}^{\text {Unabsorbed sera }} & \text { T37A } & \text { T37 abs. T37 A } & \text { T37A abs. T37 } \\ \text { Type 37 } & + & + & - & - \\ \text { Type 37 A } & + & + & - & +\end{array}$

these sera. Type 16 gave a specific reaction with one type antiserum prepared against a canned ham strain; this reaction was confirmed by absorption.

Precipitin typing. Precipitin tests with the 13 type sera described above showed good agreement with the agglutination results. With $\mathrm{HCl}$ extracts and unabsorbed sera many non-specific cross-reactions were observed. However, it was possible to remove these and, with a few exceptions, to substantiate the same serological types as by agglutination, with confirmation by absorption or reciprocal absorption tests. The antiserum which reacted with type 16 antigen by agglutination test also reacted by precipitin test; reciprocal absorption tests with a serum prepared against the original type 16 strain confirmed that the canned ham type was identical with it. The main difference between the two methods of typing was that with type 26 and its subtypes only the subtype antigens (discussed later) were revealed by agglutination test, whilst the precipitin test also showed the presence of the common type antigen. With type 37 and its subtype, however, both methods showed the same antigenic pattern. Four strains (listed as untyped in Table 2) were typed by 
agglutination but could not be by precipitin typing. The specific agglutination reactions may have been due to thermolabile unstable $\mathbf{K}$ antigens (Skadhauge, 1950) present in agglutination suspensions but likely to be destroyed in the preparation of $\mathbf{H C l}$ extracts.

The precipitin method was used for the further work described here as it is more suitable than the tube-agglutination method for the large-scale typing survey contemplated for the future with porcine isolates. For such work, the precipitin test is easily and rapidly performed and the results are clear-cut. $\mathrm{HCl}$ extracts are very stable and can be kept for more than a year and still retain their potency, whilst unstable agglutination suspensions need constant rechecking and renewing. Also, comparisons could be made more readily with the results of other workers currently studying the serological typing of group D streptococci (Elliott \& Barnes, 1959; Mr T. F. Medrek, personal communication) who are using precipitin typing.

Antisera were prepared against strains which had not reacted previously, and two more types were distinguished, making a total of 15 types. Some of the unabsorbed sera were completely specific, others required to be absorbed with organisms of cross-reacting strains. Sometimes absorption with organisms of more than one strain was necessary to obtain specificity. Absorption with a strain of Streptococcus faecalis did not remove all non-specific antibodies; thus group reactions seem unlikely to be responsible for the cross-reactions. Many of the unabsorbed sera gave such potent reactions that three different types could be pooled; this would be useful for the preliminary typing of large numbers of strains.

Subtypes. A subtype was regarded as being closely related to, but not identical with, the type strain, in having the same type antigen and also possessing an extra one. Extracts of each reacted with both sera, but on reciprocal absorption the antiserum against the main type had all the antibody removed, while that against the subtype retained its extra antibody (Table 3 ). Subtypes were differentiated in type 26 which had three subtypes, and in type 37 which had one.

Tryptic digest extracts. When tryptic digest extracts were used for ring precipitin tests with a number of types, positive reactions were obtained with specific sera. This method was only tried with 5 types, however, as the extracts obtained by this method were not as satisfactory as $\mathrm{HCl}$ extracts. The reactions with homologous serum was not so strong, and hazy cross-reactions, not previously observed, occurred with some heterologous sera. Elliott \& Barnes (1959), however, used the capillary precipitin test and not the ring test; and the former may give more pronounced reactions with such extracts.

\section{Distribution of serological types in canned hams and in guts of pigs}

Table 1 shows the number of strains falling into each type and subtype. Only with type 26 did Streptococcus faecium and unclassified strains occur in the same type, reciprocal absorption tests confirming them as serologically identical. Only two types $(26,28)$ contained strains from both canned hams and pig guts. Of ten isolates from a single canned ham, six were type 26 and four were type $26 \mathrm{~A}$. Seventeen of the other 18 isolates, each from a different canned ham, were assigned to six further types. Among the 49 pig-gut strains typed were 10 different types. Nine of the 14 pigs sampled harboured more than one serological type of group $D$ streptococci in the intestine. From one pig four different types $(28,33,34$, and untyped) were isolated. 
Untyped strains. Eight strains remained untyped. Sera were prepared against six of these but with all of them many cross-reactions occurred in addition to the homologous reaction. Absorption with any of the cross-reacting strains or with a strain of Streptococcus faecalis removed the homologous as well as the heterologous antibody and rendered the sera inactive. Not all the $\mathrm{HCl}$ extracts of group $\mathrm{D}$ streptococci tested reacted with these sera, although they reacted with a group D serum, so that it was unlikely to be a group reaction.

Additional strains of Streptococcus faecium examined. As most of the canned ham isolates were of European origin, whilst the pig gut isolates were from British pigs, some strains of Streptococcus faecium from European pigs were examined to see

Table 3. Differentiating physiological characteristics of Streptococcus faecium and unclassified group $\boldsymbol{D}$ streptoccoci

\begin{tabular}{|c|c|c|c|c|c|c|c|c|c|}
\hline \multirow[b]{2}{*}{ S. faecium types } & \multirow[b]{2}{*}{ Motility } & \multirow[b]{2}{*}{$\begin{array}{l}\mathrm{NH}_{3} \text { from } \\
\text { arginine }\end{array}$} & \multirow{2}{*}{$\begin{array}{c}\text { Rapid } \\
\text { reduction } \\
\text { of LM* }\end{array}$} & \multicolumn{6}{|c|}{ Fermentation of } \\
\hline & & & & arabi- & sorbitol & $\begin{array}{l}\text { man- } \\
\text { nitol }\end{array}$ & $\begin{array}{l}\text { meli- } \\
\text { biose }\end{array}$ & sucrose & $\begin{array}{c}\text { raffi- } \\
\text { nose }\end{array}$ \\
\hline $16,30,31,32$ & - & + & - & + & - & + & + & + & - \\
\hline $\begin{array}{l}26,26 \mathrm{~A}, 28,33,34, \\
35,37\end{array}$ & - & + & + & + & - & + & + & + & - \\
\hline 29 & + & - & + & + & - & + & + & + & $\stackrel{ \pm}{(\mathrm{sl})}$ \\
\hline 36 & - & + & tor- & + & + & + & + & + & - \\
\hline 37 A & - & + & + & + & - & + & \pm & + & - \\
\hline Not typed & - & + & + & + & - & + & \pm & + & - \\
\hline Unclassified group D $\mathbf{t}$ & ypes & & & & & & & & \\
\hline 26 & - & + & + & - & - & - & + & \pm & - \\
\hline $26 \mathrm{~B}, 26 \mathrm{C}$ & - & + & + & - & - & - & + & $=$ & - \\
\hline 27 & - & + & - & - & - & - & - & + & - \\
\hline $\mathbf{3 8}$ & - & + & + & - & - & - & + & + & - \\
\hline 39 & - & + & + & - & - & - & \pm & + & \pm \\
\hline Not typed & - & + & tor- & - & - & - & \pm & + & \pm \\
\hline
\end{tabular}

$\pm=$ some strains positive, others negative; sl. = if positive only slightly so.

* Rapid reduction of litmus milk = after $6 \mathrm{hr}$. at $37^{\circ}$.

whether they were more likely to be the same types as those found in the canned hams. Thirty-seven strains of $S$. faecium isolated and identified by Dr E. M. Barnes, from Dutch, Belgian and Danish pigs were typed serologically, by agglutination test only, against 11 of the 15 types. Only three strains fell into the types described here: two from Belgium into type 16 and another from Belgium into type 28. These results were confirmed by absorption. When type sera were prepared against three of the remaining untyped strains, seven further strains were typed.

\section{Physiological characteristics of serological types}

Biochemical and physiological tests confirmed the previous description (Barnes \& Ingram, 1955) of these streptococci. Additional tests, for the ability to produce ammonia from arginine, presence or absence of motility and fermentation of a wider range of carbohydrates were also made. Table 3 shows the differentiating characteristics of Streptococcus faecium and unclassified strains; $S$. faecium is distinguished from the unclassified group by fermentation of arabinose and mannitol. The $S$. faecium serological types were all very similar: type 29 (two strains) was differentiated 
from the others by motility and inability to hydrolyse arginine; the two strains in type 36 fermented sorbitol, and some strains in type $37 \mathrm{~A}$ did not ferment melibiose. The unclassified types were even more homogeneous: some differences in the fermentation of sucrose and melibiose occurred, and an occasional strain (one of type 29 and two of type 39) fermented raffinose weakly. Type 26 included typical strains of $S$. faecium and also unelassified strains. Strains belonging to types 16, 27, 30, 31 and 32 , and one of those in type 36 produced acid with slow or partial reduction of litmus milk (the usual reaction of $S$. faecium). Strains belonging to the other types, however, were exceptional in rapidly reducing the litmus milk (within $6 \mathrm{hr}$.); this is usually a characteristic of $S$. faecalis.

\section{Precipitin reactions of the type sera with previous type strains}

$\mathrm{HCl}$ extracts of type strains of the 25 serological types of group D streptococci of Sharpe \& Shattock (1952) and of the 5 types described by Fewins et al. (1957) were tested against our 15 specific type sera. Apart from type 16, shown to be identical

Table 4. Serological relationships betroeen different types

Types 25 and 27

$\begin{array}{ccccc}\text { HCl extract } & \overbrace{\text { T25 }}^{\text {Unabsorbed serum }} & \text { T27 } & \text { T25 abs. T27 } & \text { T27 abs. T25 } \\ \text { Type 25 } & + & + & + & - \\ \text { Type 27 } & - & + & - & -\end{array}$

Types 11, 18 and 34

\begin{tabular}{|c|c|c|c|c|c|c|c|}
\hline \multirow[b]{3}{*}{ HCl extract } & \multirow{2}{*}{\multicolumn{3}{|c|}{ Unabsorbed serum }} & \multicolumn{4}{|c|}{ Absorbed serum } \\
\hline & & & & \multirow{2}{*}{$\begin{array}{c}\text { T11 abs. T18 } \\
\text { or T34 }\end{array}$} & \multirow{2}{*}{ T18 abs. T11 } & \multirow{2}{*}{ T18 abs. T34 } & \multirow{2}{*}{$\begin{array}{c}\text { T34 abs. T11 } \\
\text { or T18 }\end{array}$} \\
\hline & $\mathbf{T} 11$ & T 18 & T34 & & & & \\
\hline Type 11 & + & + & + & + & - & + & - \\
\hline Type 18 & - & + & + & - & - & + & - \\
\hline Type 34 & - & - & + & - & - & - & - \\
\hline
\end{tabular}

with one of our types, only three cross-reactions occurred: type 25 (Streptococcus faecium) extract reacted with type 27 serum; types 11 (S.durans) and 18 ( $S$. faecium) reacted with type 34 serum. Agglutination tests done in the early part of the work had shown no reaction between suspensions of any of the previously designated $S$. faecium types and the new type antisera. Antisera prepared against types 11 and 18 gave no reaction with type 34 extract, and antiserum against type 25 gave no reaction with type 27 extract. Absorption tests, however, showed that relationships did exist (Table 4). With types 25 and 27 , although type 27 extract did not react with type 25 antiserum, type 25 extract reacted strongly with type 27 antiserum. Organisms of type 25 were also capable of absorbing all the homologous antibody from the type 27 antiserum. A similar situation occurred with types 11 , 18 and 34, but involving three strains (Table 4). It had been previously observed (Sharpe \& Shattock, 1952) that precipitin tests denoted a one-sided relationship between types 11 and 18. Attempts to demonstrate a separate type antigen in extracts of type 27 and type 34 failed. With formamide extracts and tryptic digest 
extracts a similar result to that with $\mathrm{HCl}$ extracts was obtained. Ethanol precipitation (Shattock, 1949) only gave similar but stronger reactions, and no other type antigen was found in the ethanol-soluble fraction. Extraction of the acid-soluble fraction from organisms by gentle heating to $55^{\circ}$ for $30 \mathrm{~min}$. gave the same results as heating to $100^{\circ}$ for $30 \mathrm{~min}$. and did not reveal a heat labile antigen. With acetic acid extracts no reaction occurred. To try to stimulate the formation of antibodies which would react with extracts of type 27 and type 34 , rabbits were inoculated for several courses of injections with vaccines of type 11, type 18 and type 25. A course of formol-killed organisms was followed by inoculations with organisms disrupted on the Mickle (1948) tissue disintegrator, to reveal any antigens 'deep' within the cell rather than on the cell surface. Such treatment did not, however, give rise to any additional reacting antibodies in the sera, other than weak non-specific reactions probably due to the formation of group antigen.

By quantitative absorptions, absorbing the sera several times with small quantities of organisms, it was possible with type 34 serum to obtain a weak reaction ( + in $15 \mathrm{~min}$.) with the homologous organism only and not with extracts of types 11 and 18 . With type 27 serum a relatively stronger reaction was obtained with the homologous extracts (type 27) than with the heterologous extract (type 25). An extract of another strain, 2766/1, previously reported as belonging to type 25 (Sharpe, 1952) did not react at all with type 27 serum, nor absorb the homologous antibodies from it.

The anomalous antigenic relationships described here were confirmed by gel diffusion tests. The one-sided reaction between types 25 and 27 may be due to a common antigen which is fully antigenic in type 27 , but in type 25 is only a hapten, capable of absorbing antibodies and of reacting in the precipitin test but not of giving rise to antibodies. This is the type antigen in type 27 but probably just a minor antigen in type 25 strain $\mathrm{S748}$, where it is present in its hapten state. In strain 2766/1 (also type 25) it is not present, and so cannot be the type antigen. A similar relationship may occur with the other one-way reacting types. Agglutination tests do not reveal these antigenic relationships.

\section{DISCUSSION}

Fifteen serological types were differentiated among 85 strains of Streptococcus faecium and other group D streptococci with similar physiological properties. This serological classification was based on the possession of type antigens characterized by serological specificity. Lancefield (1941) considered the type specific substance of groups D streptococci to be carbohydrate, and Elliott $(1959,1960)$ confirmed this, with the same strains of $S$. faecalis and $S$. durans. It seems likely, therefore, that the type antigen of $S$. faecium will also be carbohydrate; this requires confirmation.

Subtypes observed here were demonstrated previously in other group D streptococci by Sharpe \& Shattock (1952). The early appearance in the antiserum of the subtype antibody and the fact that with agglutination tests the subtype antigen only may be involved in the reaction suggests that it is readily available on the surface of the cell.

Motile strains of group D streptococci, many from intestinal sources, have been reported previously (Ødegaard \& Gardborg, 1953; Graudal, 1957 $a, b$; Hugh, 1959) 
with characteristics similar to those of our type 29. They appeared to resemble Streptococcus faecium most closely, although some strains fermented raffinose. However only Graudal (1957b) has described a few strains unable, like our type 29, to hydrolyse arginine; these were all pigmented organisms. The antigen demonstrated by the precipitin test is presumably the heat resistant somatic antigen of Graudal $(1957 a)$. The thermolabile flagellar antigen would be destroyed by preparation of the $\mathrm{HCl}$ extracted antigen.

Variation of physiological characteristics within a serological type is to be expected and has been noted by other investigators (Sharpe \& Shattock, 1952; Fewins et al. 1957). The latter authors found in one type a strain of Streptococcus faecium and also unclassified strains resembling the 'unclassified type 1' strains of Barnes \& Ingram (1955), which were among the strains typed here. These unclassified strains of Barnes \& Ingram are closely related to $S$. faecium except that they do not ferment arabinose and mannitol, and to $\alpha$ haemolytic strains of $S$. durans, except that they usually ferment sucrose and occasionally raffinose weakly (Shattock, 1955). The rapid reduction of litmus milk by some of the strains is, however, not typical of either of the above species. These organisms appear to be related to both $S$. faecium and $S$.durans, and the fact that some of them fall into the same serological type as strains of $S$. faecium emphasizes the similarity between the two species which is shown by physiological tests (Lake et al. 1957).

The different serological types are widely distributed, in some instances strains belonging to the same types $(16,28,30$ and 32$)$ occurred in samples from several different countries. As the sources of the canned ham and pig-gut strains were not the same it could not be expected that the same types would occur in both sources. Only types 26 and 28 occurred in both canned hams and pig intestines, but as more strains of these types were tested than any other, except type 37, this is not considered to be significant. One of the additional strains examined from pigs fell into a type previously only found in canned hams (type 16). Although type 26 occurred in canned hams and in pigs the canned ham isolates were Streptococcus faecium and the pig isolates were unclassified. It is necessary, therefore, to correlate the serological type with physiological characteristics : the unclassified type 26 strains in the pig intestine could not be the source of $S$. faecium type 26 strains in the canned hams, unless the latter have gained the ability to ferment mannitol and arabinose, which appears unlikely.

It is evident that other serological types of Streptococcus faecium exist, as only ten of the 37 additional pig gut isolates could be typed with the type sera available. Sharpe \& Shattock (1952) found that two of their types of group D streptococci from faeces of human infants were identical with two types previously described by Lancefield (1941). Elliott \& Barnes (1959) also stated that these two types corresponded to two of Lancefield's, and that two further types of Sharpe \& Shattock (1952) were identical with another Lancefield type and an isolate from bovine endocarditis. These workers isolated three of these types from chick caeca. We have found that a strain of Streptococcus faecium from Canadian Cheddar cheese, isolated and characterized by Mr P. S. Robertson, belonged to our type 26. Thus, some of the types of group D streptococci are prevalent in many different habitats. Collaboration between workers who are typing these organisms serologically is needed to prevent unnecessary replication of types. 
One of us (B. G. F.) is grateful to the Department of Scientific and Industrial Research for a grant to work on this project. The authors wish to thank Dr E. M. Barnes for many helpful discussions and suggestions, and Mr K. J. Scott for technical assistance.

\section{REFERENCES}

BARNES, E. M. (1956). Tetrazolium reduction as a means of differentiating Streptococcus faecalis from Streptococcus faecium. J. gen. Microbiol. 14, 57.

Barnes, E. M. \& INGram, M. (1955). The identity and origin of faecal streptococci in canned hams. Ann. Inst. Pasteur, Lille, 7, 115.

Barnes, E. M., Ingram, M. \& Ingram, G. C. (1956). The distribution and significance of different species of faecal streptococci in bacon factories. J. appl. Bact. 19, 204.

ElliotT, S. D. (1959). Group and type-specific polysaccharides of group D streptococci. Nature, Lond. 184, suppl. 17, 1342.

Elliotт, S. D. (1960). Type and group polysaccharides of group D streptococci. J. exp. Med. 111, 621.

ElliotT, S. D. \& Barnes, E. M. (1959). Changes in serological type and antibiotic resistance of Lancefield group $D$ streptococci in chickens receiving dietary chlortetracycline. J. gen. Microbiol. $20,426$.

Fewins, B. G., Newland, L. G. M. \& Briggs, C. A. E. (1957). The normal intestinal flora of the pig. III. Quantitative studies of lactobacilli and streptococci. J. appl. Bact. 20, 234.

Graudal, H. (1957 a). On the serology of motile streptococci. Acta path. microbiol. scand. 41, 397.

Graudal, H. $(1957 b)$. The classification of motile streptococci within the enterococcus group. Acta path. microbiol. scand. 41, 403.

HUGH, H. (1959). Motile streptococci isolated from the oropharyngeal region. Canad. $J$. Microbiol. 5, 351.

Ingram, M. \& Barnes, E. M. (1955). Streptococci in pasteurized canned hams. Ann. Inst. Pasteur, Lille, 7, 101.

INGRAM, M. \& HoBBS, B. C. (1954). The bacteriology of 'pasteurized' canned hams. J. R. sanit. Inst. 74, 1151.

Lake, D. E., Deiber, R. H. \& Niven (Jr.), C. F. (1957). The identity of Streptococcus faecium. Bact. Proc. 13.

LANCEFIELD, R. C. (1933). A serological differentiation of human and other groups of hemolytic streptococci. J. exp. Med. 57, 571.

LANCEFIELD, R. C. (1941). Specific relationship of cell composition to biological activity of hemolytic streptococci. Harvey Lect. 36, 251.

Mansi, W. (1957). The study of some viruses by the plate gel diffusion precipitin test. J. comp. Path. 67, 297.

MickLe, H. (1948). Tissue disintegration. J.R. micr. Soc. 68, 10.

ØDEGAARD, A. \& GARDBORG, O. (1953). Investigations on a motile streptococcus isolated from blood culture. Acta path. microbiol. scand. 32, 275.

Sharpe, M. E. (1952). Occurrence of a common type antigen in streptococci of groups D and N. J. gen. Microbiol. 7, 192.

Sharpe, M. E. \& Shatrock, P. M. F. (1952). The serological typing of group D streptococci associated with outbreaks of neonatal diarrhoea. J. gen. Microbiol. 6, 150.

SнAттоск, P. M. F. (1949). The streptococci of group D; the serological grouping of Streptococcus bovis and observations on serologically refractory group D strains. J. gen. Microbiol. 3, 80.

Shatrock, P. M. F. (1955). The identification and classification of Streptococcus faecalis and some associated streptococci. Ann. Inst. Pasteur, Lille, 7, 95.

Skadhauge, K. (1950). Studies on Enterococci. Copenhagen: Ejnar Munksgaard. 